\title{
Redes sociales digitales: de la presentación \\ a la programación del yo
}

\author{
Social network sites: From self- \\ presentation to self-programming \\ Rocío Rueda Ortiz* \\ Universidad Pedagógica de Bogotá, Bogotá, Colombia \\ ORCID: https://orcid.org/0000-0003-0455-2956
}

\section{Resumen}

ISSN: ISSN-OI85-4259; e-ISSN: 2007-9I76

El presente texto se basa en la investigación titulada "Formas de presentación de la persona en la red social Facebook", adelantado en Colombia. Se sustenta la tesis de que en esas redes sociales digitales confluyen diversas transformaciones: en las prácticas del representar/fotografiar, las formas de presentación de sí, en la subjetividad y la tecnicidad contemporánea. Estos cambios se conjugan en una "lógica social", posibilitada por una mediación computacional que conforma un ensamblaje sociotécnico, cuya complejidad ofrece tanto posibilidades de expansión subjetiva, individual y colectiva, como nuevas formas de homogenización y uniformización cultural.

Palabras claveः subjetividad, socialización, Facebook, identidad, imagen

\begin{abstract}
This text presents some results of the research "Ways of Self-(re)presentation on the Facebook Social Network". It will be argued that in these online social networks, several transformations converge: photographing social practices, forms of self-presentation, and changes in the current subjectivity and technicity. These changes are combined in a social logic", made possible by computer mediation which forms a complex socio-technical assembly. It offers possibilities of subjective expansion as well as new forms of homogenization and cultural uniformity.
\end{abstract}

Key words: subjectivity, socialization, Facebook, identity, image

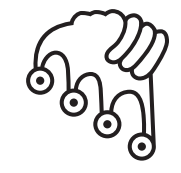

\section{IZTAPALAPA}

Agua sobre lajas

Doctora en Educación. Miembro del grupo de investigación Educación y Cultura Política de esta misma universidad y miembro ad-hoc del grupo de investigación de Educación Popular de la Universidad del Valle. rruedaortiz@yahoo.com 
1 Ministerio de Tecnologías de la Información y las Comunicaciones de
Colombia (MinTIC) dio a conocer un estudio adelantado el año pasado por
el Centro Nacional de Consultoría sobre la Cultura Digital en el país. Este se realizó con base en I 660 encuestas a nivel nacional de forma presencial a una población mayor de I2 años, entre el I5 de noviembre y el Io de diciembre de 20I3. Dentro de los hallazgos quisiera destacar que solo II \% crea, construye o recicla contenidos en la web; en este grupo, $68 \%$ usa fotografías, $56 \%$ imágenes, $42 \%$ música y $38 \%$ video. De los creadores de contenidos $84 \%$ lo hacen como aficionados, mientras que i6 \% lo hace como profesional (MinTIC, 20I4). Si bien los datos estadísticos siempre pueden relativizarse, quisiera resaltar la tendencia dominante que representan los espacios digitales, y en particular las redes sociales, para la socialización, la comunicación y el trámite de la vida cotidiana, más que para la creación y producción de contenidos (hallazgos similares en América Latina han informado, por ejemplo, Quintana, 2oro; Bringué y Sádaba, 2008; Muñoz, 2006). Sin embargo, llama la atención que de ese II $\%$ de personas que crea contenidos de manera aficionada, $68 \%$ usan principalmente fotografías e imágenes. Estas cifras muestran que la gente que está activamente conectada no hace lo mismo ni con la misma intensidad. El cambio cultural es aún lento a pesar de la velocidad de la transformación técnica. No obstante, esto no quiere decir que no podamos ir identificando tendencias y señales de un proceso de transformación social, técnica y cultural en marcha. En nuestra investigación abordamos esa pequeña porción que se dedica a crear contenidos (imágenes, textos, videos, sonidos) para su perfil en Facebook, donde consideramos se está creando una tendencia de presentación de sí articulada a una lógica "sociotécnica" que están proveyendo las actuales plataformas de redes sociales digitales.

Nuestro punto de partida es que esta tendencia se (re)produce gracias a varios fenómenos interrelacionados. Por una parte, por la infraestructura tecnológica actual que propicia una práctica social de intensa comunicación, vía correo electrónico, mensajería instantánea, "post" en las redes sociales, etcétera, y configura así un ecosistema de conectividad permanente que integra diversos dispositivos y ambientes de socialización e interacción, direccionado por una nueva lógica de los medios sociales, 
la "conectividad automatizada" (Van Dicjk y Poell, 2013:8). Por otra, por un proceso de transformación social y cultural amplio de individualización e intensificación de la experiencia (Bauman, 2007; Giddens, 199I), donde el giro de la subjetividad y de la imagen están en el centro de la batalla por el sentido. ${ }^{.}$Pero se trata de subjetividades ávidas de autonomía, deseantes, insatisfechas con el estado de cosas y expuestas a un mercado que convierte cada creación de lenguaje, conocimiento y afecto en mercancía (Rueda, 20I2c). Unas subjetividades cuya cotidianidad cada vez más se produce a través de redes de socialidad a distancia, en tiempo real, y apoyadas en diversos lenguajes y tecnologías. Los procesos de subjetivación individual y colectiva son ambiguos y contradictorios pues están jalonados tanto desde las industrias culturales, el discurso académico, la publicidad, los colectivos y grupos a los que se pertenece hasta por el actual capitalismo cognitivo (Rueda, 2012b).

Ahora bien, ¿qué papel juega la imagen en estas nuevas prácticas sociales de presentación de sí? y ¡ ¿cuál es el que desempeñan las plataformas sociales digitales, como Facebook?

Siguiendo a Inés Dussel (2010), reconocemos en la imagen una práctica social discursiva que no es nueva, sino que está en relación con los modos de producirse, de circular, y de su participación en un determinado régimen visual. ${ }^{2}$ Es decir, consideramos que la imagen "es algo más que una representación icónica suelta: es una práctica social que se apoya en esa representación pero no se agota en ella, y supone un trabajo o una operación (social, ya sea a través de la imaginación individual o colectiva, de los sentidos que le sobreimprimimos, de las tecnologías que las traen hasta nosotros)" (Dussel, 2010:6).

Pues bien, el presente texto se basa en la investigación titulada "Formas de presentación de la persona en la red social Facebook", realizado en Colombia. ${ }^{3}$ Este proyecto

I Nos referimos aquí al debate de la posmodernidad entre el sentido proveniente de un modelo racional y logocéntrico de la escritura vs. aquel originado en la emoción y los afectos que suscita la imagen.

2 Hacemos referencia aquí a las relaciones que una época establece entre lo que se ve y lo que se mira. El régimen de visibilidad dominante predispone a creer lo que en su interior se ve. En los estudios visuales se encuentran diversas posturas epistemológicas; no obstante, se comparte el presupuesto de que imagen, verdad y poder se combinan en la producción del mundo que vivimos, configurando un tipo de cultura visual dominante.

3 El estudio "Formas de presentación de la persona en la red social Facebook" (20II-20I3) fue un proyecto formulado desde la Universidad del Valle y contó con la cooperación interinstitucional de la Universidad Pedagógica Nacional y la Universidad ICEsi. En este equipo participaron como investigadores: Rocío Gómez, Diana Giraldo, Julián González, Viviám Unás, Armando Henao y Rocío Rueda Ortiz. Como monitores y colaboradores: Ana Paola Angulo, Natalia Cárdenas, Maryoli Ceballos, Mónica López, Juan Carlos Mora, Laura Parra, Jhony Velasco y Jonn Velasco. 
se propuso entender cómo una red social digital como Facebook se convierte en un espacio de experiencia y práctica social de presentación de sí, en especial desde la imagen de perfil. En este sentido, consideramos que Facebook es simultáneamente producto de la transformación de las prácticas del representar/fotografiar y de sus tecnologías, como parte de un proceso más amplio de transformación de la subjetividad y de las prácticas sociales.

Conceptualmente hemos acudido a una mirada histórica de la fotografía como práctica cultural y de presentación de sí desde el interaccionismo simbólico de Goffman. De tales presupuestos hablaremos en la primera parte de este artículo. Nuestro estudio realizó el inventario y la clasificación de 7200 imágenes de perfiles de Facebook, con base en un modelo de análisis.

Posteriormente realizamos una etnografía virtual de las páginas de Facebook de I2 personas durante seis meses consecutivos, así como entrevistas en profundidad (presenciales y por videoconferencia). Dicha etnografía nos permitió aproximarnos a una comprensión tanto de las relaciones entre las dinámicas de presentación de la persona online-offline, como de la ecología de piezas — verbales, gráficas, audiovisuales- (Gómez, 2012) que las personas ponen en marcha en el conjunto de su página de Facebook, en lo que denominamos una obra mundana. ${ }^{4}$ Sobre este inventario de imágenes, así como de algunos de los hallazgos más etnográficos hablaremos en la segunda parte de este texto. En la tercera, abordaremos lo que hemos denominado: de la presentación a la programación de sí, para resaltar el giro hacia una "lógica social" de una conectividad automatizada que las plataformas de las redes sociales digitales y en particular Facebook provee en las formas de socialización actuales apoyándonos en el trabajo de Van Dijck y Poell, así como en el de Berry. En la cuarta parte se destacan algunas conclusiones.

\section{Los álbumes de fotos y Facebook: memoria, identidad y comunicación}

GK acostumbraba a organizar sus álbumes familiares en la casa seleccionando las fotos y el tipo de festividad (cumpleaños,

4 La autora hace aquí referencia, por una parte, al carácter ecosistémico que tienen las actuales tecnologías digitales (trasmiten e intercambian datos, son interdependientes y convergentes), y por otra a las obras que realizan los usuarios en la vida cotidiana. Son mundanas, porque no pretenden ni se clasifican como obras de arte, responden más a la artesanía y la experiencia diaria de apropiación de las tecnologías. 
paseos, visita familiares de USA...) — tarea que ahora hace su mamá-. Esta actividad organizativa permeó sus álbumes de Facebook, por lo que los ha ido creando acorde a momentos importantes para él y aunque actualmente hay personas con las que no tiene ningún contacto porque se ha distanciado de ellos, todavía conserva dentro de sus imágenes su recuerdo porque han sido significativos en su vida

(Informe Etnográfico, GK, 02-2013)

Cuando miramos nuestros álbumes familiares, a pesar de haberlos visto muchas veces y del formato similar o estándar en la composición fotográfica, sentimos curiosidad y emoción, vuelven a nosotros anécdotas, recuerdos de infancia y juventud que nos erizan la piel, nos hacen sonreír y a veces nos humedecen los ojos. Parece que destella el aura de la que habla Walter Benjamin, de los que ya no están, de lo que ya no somos, y la nostalgia parece acompañarnos. Si los miramos en compañía de amigos, esta experiencia singular se convierte en una experiencia intersubjetiva, conversacional, narrativa. Entonces la imagen estática, llena de sentido para un yo emocionado, afectado, se transforma en el detonante de la memoria y de muchas historias.

Estos relatos, estas historias, capturan nuestra atención, más que las fotografías en sí mismas. La fotografía de papel, guardada en cajitas, enmarcada o pegada en un álbum, cumple principalmente una función de memoria y recuerdo, de evocación de lo vivido, es un apoyo de la función narrativa de la memoria. Así, alrededor de la fotografía se generó toda una práctica social, donde aquella cumplió una labor de soporte de la memoria, de comunicación y para compartir la experiencia. No obstante, en los últimos tiempos y con las actuales tecnologías digitales se observa un giro en dicha práctica más hacia la formación y afirmación de la identidad personal y el mantenimiento de lazos personales (Van Dijck, 2008).

Veamos un poco más los cambios. Difícilmente hacemos álbumes como antes, de papel y cartón. Ahora tenemos cientos y miles de fotografías repartidas entre cámaras digitales, celulares, BlackBerry, memorias usB, iPod, computadores personales. Ya no se marcan las fotos con papelitos escritos a máquina, una frase alusiva y el año, ahora la misma plataforma organiza cronológicamente nuestras fotos, y el dueño de estas, u otra persona de la red, puede etiquetarlas, comentarlas, transformarlas. Mostrar e intercambiar fotos es ahora un acto cotidiano, que se ha naturalizado. Ya no se trata de la fotografía hecha en un estudio, por un experto, en eventos familiares especiales; hoy se trata de una experiencia doméstica. No usamos las cámaras cuyo rollo había que mandar a revelar y esperar con ansiedad para "ver cómo quedamos" en eventos "memorables". Tomar fotografías está ahora al alcance de muchos, se puede hacer en 
cualquier momento y lugar. Podemos ver con anticipación la imagen, le podemos adicionar efectos antes y después, podemos repetirla hasta quedar satisfechos con el resultado; ya no nos preocupamos por los costos que en el contexto digital son nulos. Más aún, las fotografías, que pertenecían a una esfera privada, del entorno familiar y de los eventos especiales familiares, se han trasladado del mundo adulto al juvenil e infantil, a un espacio público digital, como el que ofrecen plataformas para compartir imágenes como Picasa, Flickr, blogs y las redes sociales digitales. En consecuencia, experimentamos una transformación tanto de las prácticas de representar/fotografiar, de sus tecnologías, como de las prácticas sociales involucradas.

Los trabajos de Sontag (2005) ya nos advertían de la manera como las fotografías se han convertido en "una gramática y una ética de la visión", de ahí que estas como objetos y como práctica social juegan un rol importante en la construcción del presente y del futuro. Roland Barthes (1989) también sugería la imposibilidad de separar el referente de la imagen y la "muerte del autor", por las múltiples posibles interpretaciones. Así el autor nace simultáneamente con su obra; no se trata de un ser que la preceda o la trascienda. Se trata de una operación de representación, de recuerdo, pero sobre todo una operación performativa pues, como señala Van Dijck (2008:58-59): "la función de la fotografía como memoria, es aún vibrante aun cuando su manifestación esté cambiando en la era digital [...] la función de memoria reaparece ahora en la naturaleza interconectada de las fotografías, en tanto son enviadas a través de redes y terminan en algún lugar virtual".

El entorno que ofrecen las redes sociales como Facebook aprovecha esta condición de las sociedades modernas y la acelera. En estas redes siempre se está en "escena", como diría Goffman (1959), se está performando una subjetividad. Inmediatez, fugacidad, interactividad, performance, visibilidad, que parecen ser condiciones de las subjetividades contemporáneas y de sus tecnologías. Pero, al mismo tiempo, consideramos que las imágenes, ahora como antes, nos hablan de la complejidad de la comunicación humana, pues en medio de la novedad tecnológica, la curiosidad, la nostalgia y la emoción de ver fotos del "pasado" parecen continuar en nuestra experiencia humana - aunque el pasado no sea lejano como el de los álbumes familiares, sino un pasado reciente de la última actualización de un perfil de Facebook-.

Esta imagen se distribuye rápidamente en la red, de manera consciente e intencional por su autor, pero también por una lógica social automatizada, que se encarga de diseminar la información por medio de protocolos de contactos y redes del ecosistema mediático (Van Dijck yPoell, 2013). También las conversaciones alrededor de las fotografías permanecen, pero ahora se trata de una conversación con "huella", que queda almacenada en estos espacios virtuales. Mientras en la época de 
la fotografía analógica, la imagen era un recuerdo "para la vida"; como plantea Van Dijck (2008), en la cultura digital se trata de recuerdos "en vivo", y esto transforma la manera bajo la cual vamos construyendo nuestra subjetividad. Finalmente, la visibilidad por medio de las fotografías tiene un efecto de espectacularización del yo (Sibila, 2008), pero también está vinculada a un temor a la invisibilidad y la consiguiente exclusión del mundo actual, pues estar en conexión implica ser visible (Winocur, 2012), no perderse de nada.

\section{La presentación de sí: de la interacción cara a cara a la interfaz digital ${ }^{5}$}

Soy plenamente consciente de que la información que compar-
tes por estas redes es vulnerable, o al menos te hace vulnerable.
Pero pienso que "conectar" no es la única funcionalidad de estas
redes. ¿Qué pasaría si no existiera esta red? Me pregunto si
mi grupo de amigos sabría lo que pienso acerca de muchas
cosas. O tal vez no sabrían de qué hablarme cuando estemos
en contacto.[... Esto no es malo, pero al mismo tiempo, haría
de la socialización un proceso más lento"

(Informe Etnográfico, MP, 05-2013).

Partimos de reconocer, como señala Schraube (1998), que no es posible hablar de lo social sin hablar de la mediación tecnológica de la existencia individual y colectiva, como una posibilidad de acción. De hecho, nuestra relación con las tecnologías ha creado siempre complejas y poderosas formas de vida, nuevas constelaciones de realidad y estructuras sociopolíticas, que no solo expanden y enriquecen la subjetividad humana y su agencia, sino que también la uniforman, le incorporan restricciones, dominación. Esto es, se trata de una acción material contradictoria (Schraube, 1998), ambigua y farmacológica (Rueda, 20I2c), ${ }^{6}$ pues no olvidemos que se trata de una

5 Retomo elementos de nuestro texto: R. Rueda y D. Giraldo (20I4), "Profile image: ways of self (re) presentation on the Facebook social network", en B. Saegret (ed.) (en prensa), Youth 2.o: Connecting, Sharing and Empowering, University of Antwerpen, Bélgica, Springer. Agradezco a mi colega Diana Giraldo por sus aportes, y en especial por introducirme en la obra de Cardon y Van Dijk, que sin duda han enriquecido y ampliado mi actual comprensión sobre las redes sociales digitales.

6 Se refiere aquí a que el fármaco puede ser remedio o veneno. Esta metáfora es usada por Platón en el Fedro a propósito de la escritura, y es retomada por Stiegler para observar ese doble carácter contradictorio, positivo y negativo, de las actuales tecnologías. 
tecnicidad impulsada por una nueva hiperindustrialización y una biopolítica que captura cada expresión subjetiva, cada creación social, para convertirla en utilidad del mercado.

Nuestra hipótesis propone que es posible observar en las redes sociales digitales la permanencia y emergencia de formas de auto(re)presentación, pues estas son el nuevo soporte material, técnico y social de las formas actuales de expresión y co-construcción identitaria. Para ello consideramos de gran utilidad el análisis microsociológico de Goffman (1959), pues si bien se centró en los encuentros cara a cara, su marco conceptual es lo suficientemente abstracto y potente como para ser aplicado en el contexto digital, que no lo pensamos aislado de aquel. Es decir, consideramos que es posible arriesgarnos a pensar en estos escenarios como espacios teatrales de la vida pública en la cotidianidad, por tres razones principales: por su carácter comunicativo y performativo, como sucede en el cara a cara; por el hecho de que en Facebook las personas tienden a presentar información "real" de sus vidas a diferencia de otros espacios donde se crea una identidad paralela, como en los entornos de videojuegos en línea, MOD, Second Life; y porque la investigación cada vez nos muestra la necesidad de atravesar la separación on/offline. Hay, por el contrario, un ir y venir permanentes, un flujo entre lo "real y lo virtual" que también toca a las identidades; por lo tanto no consideramos aquí un debate entre identidad virtual versus identidad social. No obstante, somos conscientes de que se requiere un análisis en mayor profundidad de los alcances de la obra de Goffman, así como de la naturaleza de las redes sociales digitales, y ver los límites de aquella para comprender este fenómeno, asunto del que no alcanzamos a dar cuenta en este artículo.

Nuestro reto fue observar cómo esta conceptualización nos permite comprender la actual transformación sociotécnica. Por eso, no intentamos extrapolar cada uno de los conceptos propuestos por Goffman. Nos interesó retomar su punto de partida: la gente no interactúa directamente sino que lo hace por medio de símbolos que contienen información social relevante. La presentación de sí emerge de la interacción con otros y el rol que se ocupa está siempre situado socialmente. Asimismo, nos interesó explorar la metáfora de la dramaturgia entendida como una estrategia de gestión de recursos para generar impresiones en los otros.

Ahora bien, se trata de un entorno social que, como desarrollaremos más adelante, tiene una dimensión programada, automatizada por las plataformas de redes sociales digitales. Por lo tanto, la estrategia de gestión de recursos no depende solo de la persona que se pone en escena, sino que se halla catalizada por un sistema automatizado. Así, la identidad es una coproducción donde se cruzan las estrategias de la plataforma y las tácticas de los usuarios. Esto no es posible pensarlo desde 
las formas de teatralidad y performatividad propuestas por Goffman y por lo cual acudimos a la obra de Van Dijck y Cardon.

Dos aspectos de la presentación de sí en la vida cotidiana nos parecen pertinentes para el análisis de la construcción de la autoimagen en las redes sociales digitales: en primer lugar, el papel activo de quien desea presentarse ante un público determinado, a través de la "gestión de impresiones" que se desarrolla de un modo narrativo verbal y visual; en segundo lugar, el manejo del equipamiento símbolico-expresivo de acuerdo con el escenario concreto de interacción, el cual está cargado de posibilidades y restricciones tanto materiales como sociales y donde la auto-expresión puede traducirse también en auto-promoción de sí (Van Dijck, 2013). Como plantea Serrano-Puche (2013:357), la foto de perfil vale por la persona “ya que esta escoge en función de cómo quiere ser percibida por los demás usuariosł realzando la faceta de sociabilidad, el buen humor, el atractivo físico o las capacidades deportivas". Así, detrás de la decisión de postear una imagen de perfil en una red social digital, habría que considerar por lo menos dos tipos de procedimientos: uno que está configurado por las "affordances" (posibilidades y restricciones) de la plataforma tecnológica (y su lógica social) y, otro, las posibilidades y restricciones sociales.

Siguiendo a Goffman (1959), la presentación de sí en la vida cotidiana requiere un trabajo constante de creación y de negociación. Las personas deben seleccionar y emplear cuidadosamente su fachada, en otras palabras, gestionar tanto el decorado, como la apariencia y los modales, de manera que su actuación resulte verosímil. En este sentido, la presentación de sí, más que un estado, es un proceso dinámico que implica la producción de una obra, una escenificación y se trata de un acto que no es siempre consciente y voluntario. En cualquier caso, el actor-autor invierte trabajo, tiempo y esmero. Este trabajo de presentación de sí encuentra en las redes sociales digitales un ambiente propicio para esta gestión de impresiones, no obstante su audiencia se amplía y el control sobre tales impresiones se reduce y complica.

La novedad de las redes sociales digitales es que explotan el aspecto relacional de la red mediante su invitación a conectarnos, a comunicarnos y también estimulan la creación por parte de los usuarios (se trata de una audiencia que produce contenidos o prosumers). Los internautas son convocados a tomar parte de un amplio, pero sobre todo variado repertorio de sitios web y aplicaciones multimedia que exigen la construcción de un perfil de usuario y donde, a diferencia de la interacción cara a cara, otros sujetos pueden aportar (subir, postear, compartir) información a dicha presentación de sí. Esta participación en dichas redes sociales tiene además un alto componente autobiográfico pues, como señala Cardon (2008), la identidad de las personas se encuentra cada vez más depositada y distribuida en sus obras y en los productos de 
esas actividades que se exhiben a los otros; se trata de producciones personales que difícilmente pueden ser separadas de su creador, en tanto que son testimonio de una singularidad biográfica; pero, al mismo tiempo, este ya no tiene control sobre aquella. Más aún, como sugiere Serrano-Puche (2013), cada vez que se actualiza el "estado" con comentarios, frases célebres, imágenes, videoclips, anuncios de marca, noticias, enlaces, etc., se está ofreciendo una representación de gustos y aficiones, que combina contenidos propios con aquellos que provienen de la industria y la cultura popular.

Consideramos entonces que la construcción del yo en las redes sociales digitales tiene una complejidad nueva que no conocíamos de las interacciones cara a cara o de las redes sociales de primer orden, pues la producción hecha por los usuarios requiere tanto un dominio técnico de la plataforma y cierta comprensión de su "lógica de conectividad", como una permanente e intensa actividad de intercambio social con los otros miembros de la red, la cual va generando una experiencia individual y colectiva, así como huellas sobre la red. Cardon (2008) sugiere que la construcción de la identidad es una coproducción donde se cruzan las estrategias de la plataforma y las tácticas de los usuarios. Es decir, en estas redes sociales digitales se articula de manera muy estrecha la arquitectura y programación de las plataformas, con los cálculos y tácticas que el usuario ha de considerar para lograr una mejor impresión de sí mismo.

Volviendo a Goffman, si en las interacciones cara a cara las personas se presentan a sí mismas siguiendo la lógica de una pieza teatral, en Facebook creemos que los usuarios fabrican su vida personal como una especie de obra de arte (una obra mundana), en particular en cuanto se refiere a su imagen de perfil, pero para ello además de negociar la cultura entre iguales, como se hace en el cara a cara, deben negociar sus intenciones y acciones con la "lógica social" que ofrece la plataforma digital. Ahora bien, resulta difícil hacer una identificación a priori de las intrincadas relaciones e intenciones que ponen en juego las personas a la hora de decidirse por cierta imagen, pero sí es posible reconocer y clasificar los "procesos formales" involucrados en la génesis de dicha imagen. Veamos a continuación cómo hemos abordado el estudio de la imagen de perfil en Facebook y nuestros hallazgos.

\section{La investigación sobre la imagen de perfil en Facebook}

En la primera fase del estudio, en el 20I2, nos interesó realizar un rastreo e inventario de imágenes de perfil de Facebook en 24 ciudades del mundo, lo cual nos permitiría tener un primer panorama sobre los tipos y patrones de la presentación de sí en esta plataforma. Este trabajo nos obligó a afinar un modelo de clasificación de imáge- 
nes: representante, tratamiento, encuadramiento (RTE), elaborado previamente por Gómez y González (2009, 201I). A continuación mostramos sucintamente dicho modelo para luego entrar a exponer los hallazgos.

El modelo RTE está inspirado en algunas de las categorías operativas y conceptuales de los Sistemas Dinámicos No-Lineales (atractores, auto-organización, transiciones de fase, espacio de estados del sistema, trayectorias) (cf. González y Gómez, 20II), y está conformado por tres tipos de criterios: el representante, el tratamiento y el encuadramiento de la imagen (RTE). Estos criterios a su vez contienen duplas. El tipo de representante(R) se refiere a que aquello que se usa como imagen de perfil puede considerar una figura humana o un objeto (no humano) $y$, puede, además, acentuar o no su dimensión biográfica (o mostrar huellas de la vida de la persona dueña del perfil). De esta caracterización se definen cuatro tipos de representante: humano con bio-grafos, no humano con bio-grafos, humano sin bio-grafos, no humano sin bio-grafos. ${ }^{7}$ A continuación la síntesis de los tipos de representante (R) con ejemplos: ${ }^{8}$

Gráfica I. Tipos de (R)

Humano

Con bio-grafos
Humano con bio-grafos

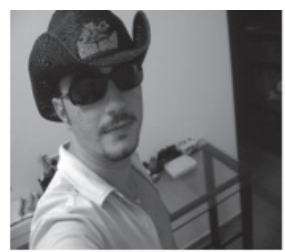

Objeto (no bumano)

Objeto con bio-grafos

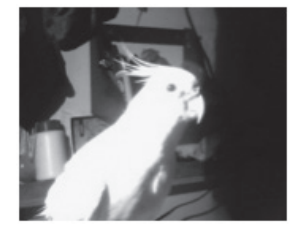

7 Somos conscientes de que los límites de estas nociones son bastante escurridizos, y entre los dos polos hay una escala de grises; así, por ejemplo, en las fotos "espontáneas y naturales" podemos encontrar elementos de "puesta en escena", de pose. De hecho, el trabajo más intenso de clasificación de imágenes se produjo en las discusiones internas del grupo de investigación, donde realizamos ejercicios de triangulación, que nos llevaron muchas veces a segundas y terceras rondas de debate para decidir dónde ubicar una imagen determinada. Por ello, para efectos de la clasificación optamos por imponernos estas demarcaciones, para facilitar el trabajo.

8 Es evidente que todas las imágenes que se suben tienen un contenido simbólico para el autor/ propietario del perfil y hacen parte de su vida (bios). Sin embargo, para efectos del modelo de clasificación que se diseñó tuvimos que optar por asumir que denominaríamos bio-grafos a aquellas imágenes que mostraran a la persona en su contexto cotidiano, y sin-biografos, a las que no mostraran ni a la persona ni su contexto. Pero es claro que, en cualquier caso, las imágenes significan "algo" para quien las sube a su perfil. 
Sin bio-grafos

Humano sin bio-grafos

Objeto sin bio-grafos
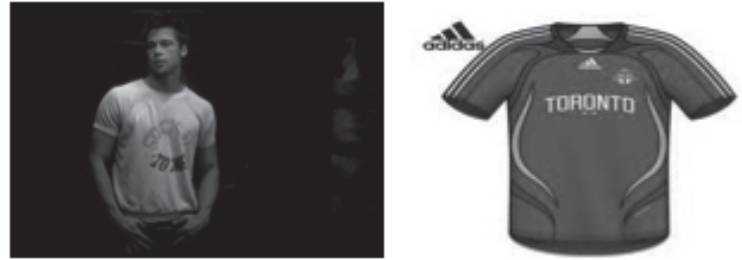

El tipo tratamiento ( imagen por medio de su manipulación y transformación o no. Este criterio se mueve entre dos opuestos: natural/artificial. La imagen puede ser a su vez no-intervenida no-escenificada, con lo cual se pretende duplicar el mundo offline adhiriendo a las convenciones sociales para representar "lo no intervenido o no manipulado", esto es, lo "espontáneo". Por otro lado, la imagen puede ser no-intervenida y escenificada, esto es, hay una puesta en escena sobre el mundo, que sirve de referente pero no hay intervención digital posterior. También puede ser intervenida y escenificada, es decir, aquella imagen que no solo abandona las convenciones sociales de la representación natural, sino que desdibuja y manipula de manera intensa las huellas del referente original, hasta hacerlo casi desaparecer. A continuación la síntesis del tipo (T) con ejemplos: ${ }^{9}$

Gráfica 2. Tipos de ( $\mathrm{T})$

Imagen no intervenida

No escenificada No intervenida

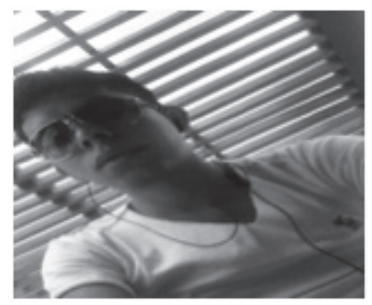

Imagen intervenida

Intervenida, no escenificada

9 Del mismo modo que con otras clasificaciones, esta dualidad escenficado/no escenificado es bastante ambigua y complicada y fue objeto de muchas discusiones. Por una parte, siguiendo a Goffman y su teoría de la teatralidad en la vida cotidiana, diríamos que cada imagen de la presentación de sí en Facebook forma parte de un ritual de escenificación y comparte una cultura de "pares" y unos valores sociales que se reconfiguran, exageran, resemantizan. No obstante, quisimos resaltar la diferencia entre las imágenes que parecían "más naturales", con "menos pose", y aquellas donde había un trabajo mayor y explícito de escenficación (y tratamiento digital). 
Imagen no intervenida

Escenificada No intervenida, escenificada

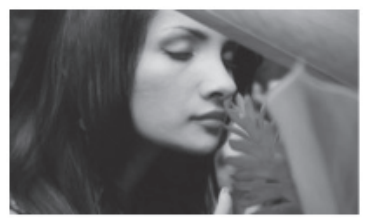

Imagen intervenida

Intervenida, escenificada

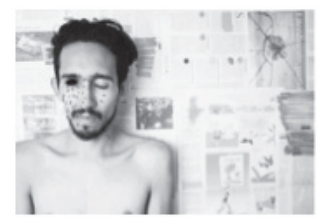

El encuadramiento (E) se refiere a la fracción del mundo social que se toma en la imagen de perfil, nombra la dupla todo-parte. Si bien toda representación es un recorte o una fracción de la realidad, las representaciones pueden aspirar intencionalmente a crear una idea de totalidad o abandonar tal tentativa. En este eje son posibles cuatro tipos de encuadramiento: unidad con contexto amplio, unidad con contexto restringido, fracción con contexto amplio y fracción con contexto restringido. A continuación la síntesis de los tipos de (E) con ejemplos;

\section{Gráfica 4. Tipos de (E) \\ Unidad-contexto \\ Fracción-contexto}

Con contexto Unidad con contexto amplio

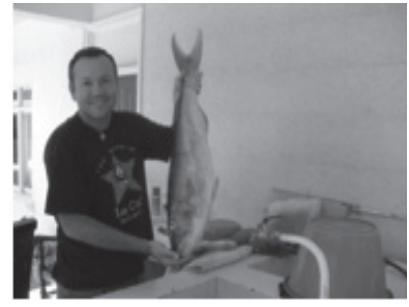

Sin contexto Unidad con contexto limitado (o contexto limitado)
Fracción con contexto amplio

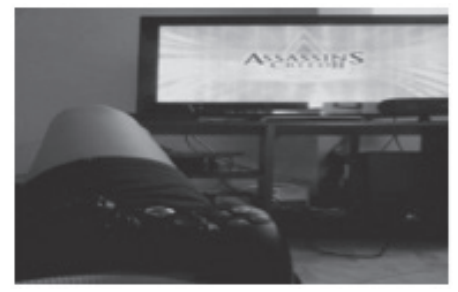

Fracción con contexto limitado

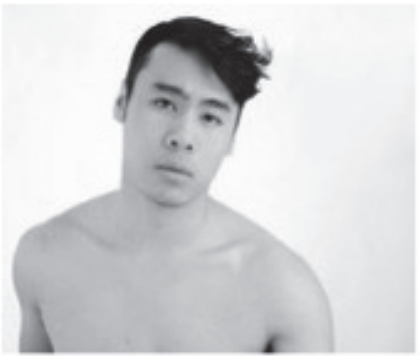


Finalmente, el modelo RTE permite construir 64 configuraciones posibles derivadas de las combinatorias de los tres criterios y sus respectivos cuatro valores, como se observa en el siguiente cuadro síntesis:

Gráfica 4. Configuraciones posibles derivadas de los tres criterios

$\begin{array}{llllllll}\text { RITIFI } & \text { RIT3FI } & \text { R2TIFI } & \text { R2T3FI } & \text { R3TIFI } & \text { R3T3FI } & \text { R4TIFI } & \text { R4T3FI } \\ \text { RITIF2 } & \text { RIT3F2 } & \text { R2TIF2 } & \text { R2T3F2 } & \text { R3TIF2 } & \text { R3T3F2 } & \text { R4TIF2 } & \text { R4T3F2 } \\ \text { RITIF3 } & \text { RIT3F3 } & \text { R2TIF3 } & \text { R2T3F3 } & \text { R3TIF3 } & \text { R3T3F3 } & \text { R4TIF3 } & \text { R4T3F3 } \\ \text { RITIF4 } & \text { RIT3F4 } & \text { R2TIF4 } & \text { R2T3F4 } & \text { R3TIF4 } & \text { R3T3F4 } & \text { R4TIF4 } & \text { R4T3F4 } \\ \text { RIT2FI } & \text { RIT4FI } & \text { R2T2FI } & \text { R2T4FI } & \text { R3T2FI } & \text { R3T4FI } & \text { R4T2FI } & \text { R4T4FI } \\ \text { RIT2F2 } & \text { RIT4F2 } & \text { R2T2F2 } & \text { R2T4F2 } & \text { R3T2F2 } & \text { R3T4F2 } & \text { R4T2F2 } & \text { R4T4F2 } \\ \text { RIT2F3 } & \text { RIT4F3 } & \text { R2T2F3 } & \text { R2T4F3 } & \text { R3T2F3 } & \text { R3T4F3 } & \text { R4T2F3 } & \text { R4T4F3 } \\ \text { RIT2F4 } & \text { RIT4F4 } & \text { R2T2F4 } & \text { R2T4F4 } & \text { R3T2F4 } & \text { R3T4F4 } & \text { R4T2F4 } & \text { R4T4F4 }\end{array}$

\section{El modelo RTE y 7200 imágenes en 24 ciudades del mundo}

El inventario y la clasificación de las 7200 imágenes de perfiles de Facebook repartidas en 24 ciudades del mundo siguió entonces el modelo de clasificación de imágenes RTE (representante, tratamiento, encuadramiento) antes descrito. ${ }^{10} \mathrm{La}$ información se expone a continuación de manera global pues el interés es presentar las principales tendencias; por lo tanto, no se ofrece un análisis intercultural comparativo entre las ciudades. Esto sería objeto de otro artículo.

Io Las ciudades elegidas fueron: Bogotá, Buenos Aires, Caracas, Ciudad de México, La Habana, São Paulo, Chicago Montreal, Nueva York, Toronto, Berlín, Londres, Madrid, París, Roma, Pekín, Bombay, Islamabad, Tel Aviv, Pionyang, Tokio, Johannesburgo, Nairobi y Sídney. 
El hallazgo más llamativo fue encontrar lo que hemos denominado el canon de la imagen de Facebook en el estudio, esto es, la imagen de perfil "típica" del tipo (RITIEI): humano con bio-grafos, no intervenida-no escenificada y unidad-con contexto amplio en todas las ciudades elegidas, tanto en aquellas con una infraestructura tecnológica extendida y con alta conexión a internet, como Berlín, Londres o Buenos Aires, como en aquellas con menor infraestructura y acceso como La Habana, Nairobi o Islamabad.

De un total de 7200 páginas revisadas, $74 \%$ (5337 imágenes) corresponde a este tipo. Hay catálogos como los de São Paulo (con 287 imágenes) y Tel Aviv (286 imágenes), en los que casi la totalidad está concentrada en el tipo I. Así, $83 \%$ de las imágenes del catálogo son fotografías de lo que denominamos "al natural y espontáneas" (no hay retoques, montajes, etc.). Adicionalmente, $97.44 \%$ son de cuerpos completos. Tampoco se intervienen o escenifican de modo especial. Solo io \% acude a objetos, animales, cosas, paisajes y entidades no humanas. Casi la mitad de las imágenes estudiadas ( $54 \%$ ) corresponde a capturas y registros digitales de cuerpos y rostros que revelan además porciones importantes del entorno de vida cotidiana de los sujetos (esto es, con huellas bio-gráficas).

Respecto de las imágenes tipo 2 (humano sin bio-grafo), encontramos 876 , esto es, únicamente I2 \% del total de 7200 páginas analizadas. En general se aprecia el recurso a una iconografía mediática (personajes del mundo de la televisión, el cine, el periodismo escrito y audiovisual, los deportes, la música y los videojuegos) e iconos religiosos (Buda, Cristo). Se destacan principalmente Bombay por el uso de imágenes relacionadas con el mundo artístico y cinematográfico, y Tokio por la presencia de imágenes relacionadas con el mundo del manga. En el catálogo de Islamabad y el de Sidney se encontró un número significativamente alto de imágenes de humano sin bio-grafos.

Las imágenes del tipo 3, es decir, no humano con bio-grafos, tienen poca presencia dentro de los catálogos analizados: 132 imágenes; es decir, I.8\% del total. El catálogo con mayor número de imágenes tipo 3 es el de Madrid, con 19. En algunos otros como los de Islamabad, Johannesburgo y Tel Aviv no encontramos ninguna de estas.

Respecto del último tipo, imágenes 4 , no humano sin bio-grafos, su presencia es un poco más significativa que la del tipo anterior: $56 \mathrm{I}$ imágenes; esto es, casi $8 \% \mathrm{del}$ total de páginas de Facebook analizadas. La presencia de imágenes no humanas y sin bio-grafos es relativamente importante en los catálogos de Madrid (6r imágenes, o sea, $20 \%$ del total de su catálogo), Islamabad (5I: $17 \%$ de su catálogo) y Nairobi ( $45: 15 \%$ de su catálogo). 
Otro de los hallazgos relevantes es que ir \% de imágenes que corresponden a cuerpos y rostros provienen de los medios y las industrias culturales, en contextos restringidos y sin marcas evidentes de intervención ni de escenificación. Esto es, una imagen del "personaje" (cantante, actor, deportista, imagen religiosa) reemplaza la presentación de sí de la persona propietaria de la página de Facebook sin dejar resquicios de su mundo cotidiano. Este sería un caso extremo de uso de la "fachada" en términos goffmanianos. El catálogo de Bombay es un ejemplo interesante de este tipo de imágenes ( 133 fotografías) del tipo 212: humano sin bio-grafos, no intervenida/no escenificada, unidad con contexto restringido. En el catálogo de Tokyo fue difícil distinguir imágenes del mundo offline de las que provienen del mundo digital. Uno de estos casos fueron los lentes de contacto "tipo anime", los cuales producen un efecto de agrandamiento de los ojos.

En suma, encontramos un ambiente de presentación y exposición de sí, donde imágenes de las personas autoras del perfil predominan (sobre imágenes de animales u objetos) y al mismo tiempo ofrecen información biográfica de su vida cotidiana; es decir, hay una tendencia a la presentación de sí "al natural" ante otros. Pero también, siguiendo a Goffman, se prueban diversas máscaras que provienen del mundo de la industria y la cultura popular. ${ }^{11}$ No obstante, hay también una tendencia menor, especialmente entre las personas más jóvenes, a hacer una mayor escenificación e intervención sobre la imagen. A ello dedicaremos el siguiente apartado.

\section{Tratamiento y escenificación: capturar el momento, posar y postear}

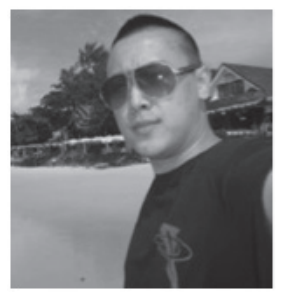

Como se dijo antes, siguiendo el trabajo de Goffman, toda presentación de sí tiene un componente de "puesta en escena". No obstante, en nuestro estudio quisimos observar esa escenificación consciente y que exige un trabajo adicional (humano y técnico), a través de acciones de pre y producción de la imagen en Facebook. Encontramos que construir la imagen de sí, se ha

II Aquí sería interesante hacer una revisión más profunda que retome las categorías que desarrolla Goffman en su texto Gender Advertisements (1979), donde analiza cómo la publicidad tiende a la normalización, exageración y simplificación extrema. En particular, propone observar varios patrones de representación a través de los cuales se muestra el género, como: "tamaño relativo", "tacto femenino", "ordenamiento de funciones", “la familia”, "ritualización de la subordinación” y "retirada permitida". 
convertido en una práctica de captura y representación del instante, debido, entre otras razones, a la expansión y multiplicación de oportunidades de captura digital de todo tipo de escenas, eventos y acontecimientos de la vida cotidiana, desde diferentes dispositivos tecnológicos, especialmente los celulares. Esto parece llevar a una suerte de fusión del acontecimiento con su registro fotográfico: la experiencia del mundo se vuelve una "ocasión para estar posando"; estar en un lugar es estar tomando imágenes. Quizás a ello se deba la gran cantidad de fotos que denominamos "típica" del tipo (RITIEI), "espontáneas y naturales", pues es tal la urgencia de generar "recuerdos en vivo y en directo" que no hay tiempo de editarlos. ${ }^{12}$

No obstante, tal espontaneidad es relativa, pues de hecho, y en medio de la diversidad de ciudades revisadas, existe una tendencia similar en cuanto al tipo de mirada, de sonrisa y de gestualidad corporal. Es probable que cierta "forma de mirar y ser mirado" homogénea en Facebook se deba a ese régimen visual dominante de los medios masivos y la publicidad, que forma parte de los tipos de percepción global que comparten hoy muchos jóvenes en el mundo. Como plantea Goffman (1979), en su texto Gender Advertisements, las expresiones usadas por los publicistas son recibidas y transmitidas como si fueran algo natural; de esta manera, la publicidad ritualiza lo que ya está ritualizado, es decir, toman las manifestaciones de género (y podemos adicionar: de clase, de raza, de región) que compartimos socialmente y las reconfiguran, exagerándolas. Esto lo podemos extrapolar a aquellas personas jóvenes en Facebook cuyas autopresentaciones buscan poses llamativas, y para ello toman como referente la publicidad y las industrias culturales, y reproducen y alteran también algunos estereotipos.

\section{Efectos visuales y estética retro}

En la intervención de imágenes del tipo humano con bio-grafos - que requiere acciones de posproducción sobre la imagen digitalizada - es frecuente encontrar una importante tendencia a hacer todo tipo de "retoques" posteriores al momento de la captura de la imagen. Especialmente los más jóvenes exploran la forma de presentación de sí por medio de diversos dispositivos

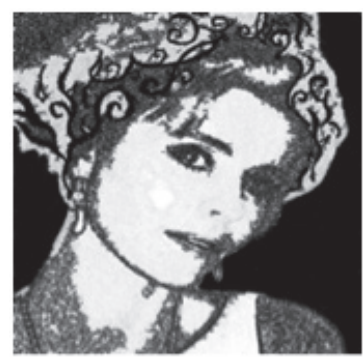

12 Esta práctica también genera imágenes desechables, "imágenes-kleenex: de usar y tirar", como las llama Fontcuberta (2010). 
y acuden al uso de software para editar la imagen, como Photoshop u otros similares. También encontramos una tendencia concentrada en imágenes en blanco y negro que, moviéndose dentro de la escala de grises, producen texturas interesantes para nuestra mirada cada vez más saturada de colores. Esta tendencia (presente en todos los catálogos estudiados) puede ser un pequeño indicio de la emergencia de prácticas y estéticas del tipo "retro" que, en medio del régimen visual dominante y dadas las condiciones tecnológicas actuales de captura y registro de imágenes, podrían aparecer como obsoletas. Quizás la vuelta a lo viejo, lo gastado, sea una forma de producir "novedad" en el entorno comunicativo contemporáneo, asunto que por cierto la publicidad también aprovecha y tiende a normalizar y ritualizar. No obstante, como lo mencionamos antes, del total de imágenes analizadas solo $13.73 \%$ corresponde a rostros o cuerpos humanos que además de ser explícita y claramente escenificados también son intervenidos.

Esta ausencia de altos niveles de exploración gráfica y técnica incluso en ciudades con alta penetración tecnológica, como Buenos Aires, París, Nueva York o Londres nos hace pensar, por un lado, que la poetización escénica y por lo tanto la actitud artística en estas nuevas formas de presentación de sí, en muchos casos, no ocurre en la obra-foto de perfil (como objeto de experimentación artística), ni en la fuente (el momento, las personas, la escena precisa), sino que se produce en el encuentro de los dos, esto es, en ese proceso de exploración incansable del yo en el mundo cotidiano y en su captura a través de tecnologías de la imagen, instituyéndose mutuamente. Pero por otro lado, hay que considerar las affordances (entendidas como posibilidades y limitaciones) de la plataforma: Facebook no "facilita" la producción de contenido visual. Su sistema promueve la actualización permanente de la página, pero no ofrece directamente herramientas para la edición digital de dicho contenido, así que los usuarios interesados en ese trabajo de posproducción tienen que hacerlo por medio de otros dispositivos y luego subirlo a la página respectiva.

Otro de los hallazgos es que en muchos casos hay más tareas de exploración y experimentación de la presentación de sí en los álbumes de los usuarios, que en los archivos de la imagen de perfil, pues esta de alguna manera es decisiva en la identificación de un sujeto en la red social de Facebook; por lo tanto, al elegir una imagen, los usuarios deben sopesar, al mismo tiempo, sus necesidades de presentación y reconocimiento en dicha red (las affordances sociales), y las tentativas de experimentación expresiva de su imagen y los posibles efectos comunicativos (las affordances de la plataforma). La experimentación con la imagen de sí puede disolver o amenazar la identificación o el reconocimiento de la persona. Así, muchos usuarios crean álbumes temáticos donde se encuentran imágenes de diverso tipo, desde 
aquellas donde hay un claro tratamiento y experimentación visual, hasta otras que documentan y registran temas de interés o hechos de la cotidianidad, entrelazados con notas (etiquetas, comentarios, títulos) que refuerzan los vínculos en la red social.

\section{Sobre los mundos de la vida}

Nuestra aproximación a los mundos de la vida de 12 personas ${ }^{13}$ nos permitió ver, en un segundo momento de nuestro estudio, que los sujetos no son simples ensamblajes del cambio tecnológico, pues existe todo un sustrato cultural que otorga unos valores y unas dimensiones de uso. Este es el caso de los mundos de la vida familiar y filial que aparecen con gran intensidad en las páginas de Facebook de los sujetos que participaron en nuestro estudio. ${ }^{14} \mathrm{La}$ familia es, especialmente para los adultos, ese horizonte desde donde se dota de sentido la presentación de sí y desde el cual se produce una obra vincular en Facebook que permite mantener, reconstruir y cuidar los lazos familiares. De hecho, en las imágenes de perfil suelen aparecer fotos de los hijos, nietos o fotos de pareja y familia. Así, encontramos que para la población adulta lo más importante en el uso de Facebook no es la experimentación visual de la imagen de sí, sino el mantenimiento del vínculo familiar. Para los más jóvenes, si bien la familia no desaparece como ámbito de sentido, no tiene la misma presencia e intensidad en la presentación de sí que para los adultos. Este lugar lo ocupa el mundo de la amistad y el amor, que aparece como un universo de sentido central en la "habitancia" de Facebook. En términos del uso de la imagen en la presentación de

13 Esta información fue recogida, por una parte, a través del instrumento de seguimiento que se diseñó para el estudio y que fue aplicado en dos temporalidades: fin de semana y entre semana y, por otra, se complementó, a partir de los hallazgos provenientes del trabajo etnográfico realizado durante seis meses y la realización de entrevistas en profundidad (presenciales y vía videoconferencia). El grupo de sujetos (I2 personas) estuvo compuesto por cinco mujeres y siete hombres, distribuidos así: ocho entre los 20 y los 30 años de edad (cuatro mujeres y cuatro hombres, el grupo más joven del estudio); dos hombres entre 30 y 50 años de edad (conforman el grupo de adultos) y uno de 70 (una mujer adulta mayor). La mayoría de personas del grupo (ocho) pertenecen a una generación joven "universitaria" de clase media de la ciudad de Cali, Colombia. Estos jóvenes son estudiantes de humanidades y ciencias sociales: historia, sociología, comunicación social, medios audiovisuales e interactivos, publicidad, recreación y educación popular. Finalmente, los dos adultos hombres están dedicados a sus trabajos profesionales (en la comunicación y el turismo) y la adulta mayor está pensionada.

I4 Otros escenarios importantes fueron las agrupaciones y los colectivos juveniles a los que pertenecían algunos sujetos que participaron en el estudio, en temas de medio ambiente, género, mujer, arte, entre otros. 
sí, mientras las generaciones mayores concentran su uso como conmemoración familiar, como una preservación de la memoria y captura de la realidad, los más jóvenes lo ven como opción para estar en contacto con su círculo filial y para construir su identidad. Sin embargo, estas formas de presentación de sí propias de la interacción cara a cara se modifican cuando se establece el puente off-online, pues tal presentación se hace extensiva a un público que actualiza, comenta, disemina y colabora en su construcción. De hecho, algunos jóvenes cooperan en las ediciones digitales de las imágenes de perfil de otros amigos. Asimismo, ellos han aprendido en su experiencia en Facebook a desarrollar tácticas para seleccionar su grupo de "amigos", afinar restricciones en el acceso a sus páginas y "calcular" los efectos de subir un tipo de imagen u otra, pues los procesos de socialización se aligeran, anticipan, aceleran, pero también se complican. Hay menos de la euforia inicial de "exhibicionismo" en la plataforma y más el interés por cuidar el grupo de amigos seleccionado y a quien se le permite o no hacer cambios en la presentación de sí. En especial aquellas personas que viven una exploración de género, observan con mayor intensidad los efectos que tiene el vínculo off-online en estas redes sociales, por lo cual inventan tácticas de (in)visibilización respecto de sus vínculos amorosos y sus apuestas políticas sobre el género; usan "códigos secretos" que solo comprenden las personas afectivamente más cercanas (como usar un videoclip, una canción, un eslogan).

En suma, vemos que no se trata de un cambio abrupto, radical, en donde hay una identidad virtual y una real, sino que las formas de exploración y presentación de sí se producen sobre prácticas y valores sociales existentes, donde prejuicios y estereotipos siguen jugando un rol en la interacción diaria on y off line, son retomados, reproducidos y ritualizados (en el sentido que critica Goffman) por el régimen visual dominante que producen diversos dispositivos de la industria de medios y entretenimiento, y en particular las redes sociales digitales como Facebook. A continuación abordaremos con mayor detalle la agencia que poseen dichas plataformas en la configuración de formas de presentación de sí.

\section{De la presentación a la programación yo}

No somos ingenuos en creer que el actual cambio sociotécnico es tranquilo y feliz, pues las prácticas que realizan los sujetos en estas redes sociales digitales si bien tienen que ver con un mundo (inter)subjetivo, familiar y fraternal, también están vinculadas a un régimen de visualidad dominante, a unos valores de una sociedad de consumo y a una lógica de mercado que exige cada vez más estar "conectados". No 
consumir y no estar conectados produce sufrimiento y exclusiones de las formas de vida actuales. Condiciones subjetivas que el mercado sabe capturar y modular muy bien a través de una perversa lógica de lo útil y parte de la actual economía capitalista y de la "lógica social" de estas plataformas digitales. Si bien nuestro estudio no consideró un análisis de las formas de presentación de sí en relación con esta lógica social de las plataformas como Facebook, como uno de sus objetivos, por el camino nos fuimos encontrando con la importancia de llamar la atención sobre el tema, y siguiendo la metáfora de la dramaturgia de Goffman, donde la presentación de sí es una estrategia de gestión de recursos para generar impresiones en los otros, encontramos cierta homogenización en la revisión de las imágenes, donde prevalecen fotos con ciertas poses, gestos, sonrisas. En algunos casos señalamos que hay un trabajo de pre y posproducción de las imágenes, que interviene aún más la presentación de sí en Facebook. No obstante, la estrategia de gestión de recursos no depende solo de la persona que se pone en escena, sino que se halla catalizada por un sistema automatizado. Así, vemos que la identidad es una coproducción donde se cruzan las estrategias de la plataforma y las tácticas de los usuarios, asunto que no es posible pensar desde las formas de teatralidad y performatividad propuestas por Goffman. A continuación destacamos los elementos que nos parecen más relevantes y que nos llevan a considerar que además de una presentación hay una programación de sí.

La caracterización de esta lógica social de las plataformas digitales la haremos de la mano del trabajo de Van Dijck y Poell (2013) y Berry (20II), aunque este último lo denomina "enmediación computacional". Esta lógica o "enmediación" se refiere a los procesos, principios y prácticas mediante los cuales estas plataformas procesan la información y la comunicación y cómo "canalizan" la interacción social de una manera que parece neutral y estandarizada, bajo algoritmos y scripts informáticos. Esto es, la interacción de la vida cotidiana pasa a ser tramitada por una enmediación computacional de la que apenas nos estamos percatando y que es casi invisible a nuestros ojos. Van Dijck y Poell (2013:5 y ss.) han identificado cuatro estrategias y mecanismos de dicha lógica que actúan de manera interdependiente: programabilidad, popularidad, conectividad y datificación. Facebook,como otras redes sociales digitales, es una plataforma tecnológica que afecta las formas de construir lo social, a partir de "clasificar", "etiquetar", "compartir", "recomendar" y "relacionar amigos", o "la gente que usted puede conocer", a través de un script informático que "sugiere" relaciones sociales a partir de datos inferidos. La programabilidad se refiere tanto a la capacidad de estas plataformas de medios sociales para desencadenar y dirigir las contribuciones creativas o comunicativas de los usuarios como a la capacidad de estos de cambiar, por medio de la interacción con aquella, la influencia y el flujo 
de la información y comunicación activada por la plataforma. Esta agencia de los usuarios es la que hace posible no solo contribuir a alimentarlas, sino también a crear resistencia a las estrategias de mercado y a las instrucciones cofidicadas o a los protocolos por defecto de estas plataformas. Sabemos que, por ejemplo, frente a la noticia sobre la venta de información de los usuarios por parte de Facebook, muchos organizaron protestas en la misma red, bloquearon protocolos, obligando a ajustar las políticas de privacidad. Facebook entonces tampoco es totalmente autónomo, tiene que complacer tanto a sus millones de usuarios como a sus anunciantes.

La popularidad es un mecanismo que proviene de los medios masivos y con un enorme poder para crear personalidades mediáticas. Este mecanismo se ha hecho más complejo en plataformas digitales como Facebook, pues al igual que la programabilidad, este mecanismo tiene componentes algorítmicos y socioeconómicos para impulsar la popularidad de personas, cosas, ideas, lo cual es medido principalmente en términos cuantitativos (cuántos amigos tienes, cuántas personas han leído tus post, en qué ranking te encuentras, etcétera). Así, por ejemplo, los algoritmos de "me gusta" de Facebook automáticamente seleccionan evaluaciones emotivas y positivas de ciertos temas, y se evade cuestionar o plantear argumentos complejos. El mecanismo de "me gusta", al tiempo que genera una cierta experiencia social compartida, produce una "economía automática de lo que gusta", que se integra al régimen visual que se extiende a los medios masivos, como la televisión y la radio. Se trata de un mecanismo de medición de la popularidad que en forma simultánea y, por los mismos medios, intenta influenciar y manipular tales rankings. De hecho, en nuestro estudio encontramos que algunos jóvenes usan la plataforma de Facebook también con objetivos comerciales y sociales. Desde vender obras, productos, ofrecer servicios, hasta promover causas por el medio ambiente, el género y la no violencia contra la mujer. Los índices de popularidad pueden ser muy útiles para dichos objetivos. Así se "exporta" este mecanismo de las plataformas digitales a otros ambientes sociales y comerciales, desafiando los órdenes sociales y las jerarquías discursivas.

La lógica de la conectividad si bien es una expresión del mundo tecnológico, se refiere a una posibilidad sociotécnica de las redes para relacionar los contenidos de las actividades del usuario y los anunciantes. En un ecosistema social conectivo, las plataformas digitales median las actividades de los usuarios y definen la forma que toman las conexiones, aun cuando aquellos tienen una influencia considerable sobre sus contribuciones y contenidos. Sin embargo, para Van Dijck y Poell (2013), la conectividad no tiene que ver solo con la conexión de individuos sino que enfatiza la conformación mutua de usuarios, plataformas, anunciantes y la "actuación" o performance del ambiente online. De esta manera aparece una nueva paradoja en 
esta lógica social de las plataformas digitales, pues al lado de la programabilidad y la popularidad, la conectividad representa una estrategia que posibilita la conexión entre humanos, y al mismo tiempo la fuerza "artificialmente" a través de una conectividad automática. La conectividad, como lo hemos visto de la mano de movimientos y actores sociales, pero también de la mano de individuos comunes, puede favorecer procesos de participación política desde abajo; es usada para reconfigurar y establecer jerarquías entre intereses privados, públicos y corporativos.

Esta conectividad, así como los otros dos mecanismos: programabilidad y popularidad, está basada en la "dataficación". Se trata de sistemas online de tratamiento de datos en "tiempo real" para calificar, sondear, evaluar e incluir las respuestas de los usuarios dentro de la arquitectura de las plataformas. De ahí que Facebook haga seguimiento del "tráfico social" en la plataforma en relación con indicadores de temas de moda, palabras claves, tendencias, sentimientos, puntos de vista y los ítems que son compartidos con mayor frecuencia y los que más han gustado. Esta condición de tratamiento en tiempo real (o el aparente tiempo real) se traslapa con aquella que conocemos de los medios masivos como transmisiones "en vivo". El mejor ejemplo de esta condición la vemos en los debates políticos de candidatos presidenciales, para los cuales tanto la televisión como la mensajería instantánea están generando una esfera pública. De nuevo, estas interfaces en tiempo real dan poder a los usuarios en formas complejas pues, por una parte, favorecen la acción personal, la libertad de expresión y, por otra, tales plataformas orientan y explotan las actividades de los usuarios, según los intereses corporativos subyacentes.

En suma, esta nueva lógica social, con los mecanismos antes descritos en plataformas como Facebook, se alimenta de la actividad constante y permanente de millones de usuarios, instituciones, anunciantes, empresas; consume, en gran parte, nuestra atención psíquica y social y, a pesar de contar con un dispositivo escritural que virtualmente posibilita el diálogo, se sustenta en una lógica del corto o muy corto plazo, en la hiperabundancia de información y comunicaciones, y en una conciencia cuya fluidez reduce los tiempos de reflexión (Rueda, 20I2c). Lo que leemos detrás de cierta uniformización de la cultura en las miles de imágenes analizadas de Facebook en diferentes ciudades del mundo es que debemos estar alertas a la apropiación y el monopolio de la información producida en dichas plataformas (imágenes, textos, sonidos, etc.), por cuenta de las industrias de medios que, junto a una lógica de mercado, configuran un tipo de memoria y régimen visual planetario: el que se ajusta a un solo modo de vida posible ( $y$ a valores que tienen que ver con el éxito, la rentabilidad, competitividad y el consumo). 
La paradoja, sin embargo, es que también por medio de dichas plataformas se están cuestionando órdenes y jerarquías sociales, políticas y culturales, se están produciendo formas novedosas de invención social (Rueda, Fonseca y Ramírez, 2013). Estas se han convertido en la nueva estructura material de nuestra humanización, de exploración de las identidades y de movilización política, pero no son la fuente única ni directa de dicha transformación. En otras palabras, los procesos de subjetivación se producen en una tensión de la individualidad/colectividad en dos niveles: un otro exterior y una singularidad interior, cuyo encuentro actualiza potencialidades subjetivas (sea un sujeto o un colectivo). De ahí que la subjetividad (o individualidad o la identidad) sea un proceso y no una esencia. $\mathrm{Y}$ esta no deje de individualizarse a través de interacciones y resonancias con los otros (amigos, familia, escuela, industrias culturales, ecosistema tecnológico). Por ello consideremos fundamentales los estudios que logren observar, mediante una exploración sistemática, la manera compleja y contradictoria en que nuestras subjetividades se están configurando a través de dicha infraestructura material y de cómo transitamos de formas de presentación de sí, en el cara a cara de las redes sociales de primer orden, a las formas de programación de sí que se están configurando con las plataformas de redes sociales digitales o de segundo orden.

\section{Conclusiones}

Retomando la pregunta que orientó este texto sobre el papel que juega la imagen en las nuevas prácticas sociales de presentación de sí y el de las plataformas sociales digitales, como Facebook, encontramos que la imagen, como la fotografía, es un activante de la memoria, pero sobre todo es un puente de comunicación, visibilización y reconocimiento con - $y$ entre- otros y un detonante de relatos. Estas narraciones, que en las prácticas sociales alrededor de la fotografía fueron orales, en las redes digitales responden a una oralidad secundaria, donde hay textos, imágenes, sonidos, cuyas huellas son almacenadas. En efecto, la presentación de sí mismo a través de la imagen de Facebook es el resultado de una permanente tensión entre las affordances de un ecosistema comunicativo que la plataforma ofrece y canaliza por medio de programas y scripts en lo que se ha denominado una lógica social automatizada y las estrategias y el entramado de decisiones y procedimientos que los usuarios realizan con base en el contexto de interacción social en el que se encuentran. De ese modo, la presentación de sí hoy se configura a partir de la interacción de diversos dispositivos sociales y tecnológicos, y los valores que tramitan. Se destaca la influencia de 
las industrias culturales y el mercado en los procesos de subjetivación que tienden a generar prácticas culturales homogéneas y uniformes alrededor de la presentación de sí, y esto a nivel global, por lo cual consideramos tienen gran influencia en el régimen visual contemporáneo dominante.

Aunque algunos autores han criticado la aproximación de Goffman porque le da demasiada relevancia a las reglas y reconoce menos aspectos relacionados con la improvisación o el hábito de animarnos unos a otros en la interacción cotidiana, encontramos que su conceptualización, si bien no es suficiente (de ahí que acudimos a otros autores), sigue siendo muy importante para entender las formas de presentación de sí en las redes sociales digitales como Facebook. De hecho, consideramos que la experiencia subjetiva en esa red social no está predeterminada, pero sí está ligada a un conjunto de reglas, protocolos y condiciones de interacción y comunicación que ofrece dicha plataforma, así como a las reglas de interacción que se producen dentro de grupos sociales. Por ello, encontramos que alrededor de la imagen de perfil se deben leer también el conjunto de las piezas comunicativas que integran la página (el escenario), una clase de "frente" con los elementos materiales que le rodean (imágenes, textos, símbolos, música, etc.), la apariencia (información acerca del usuario disponible en la plataforma), y las reglas, normas y valores de interacción que se espera que los usuarios tengan y las que estos a su vez van creando (el paso del Facebook del "libro de contactos" a la actual Facebook "biografía" justamente muestra cómo la plataforma tecnológica interpreta la actividad de los usuarios y se adapta para alcanzar más públicos, o las mismas protestas de los usuarios por las normas de privacidad de datos que obligaron a Facebook a cambiar ciertos protocolos). De ahí que, como plantea Goffman, el sentido social de las acciones que realizan las personas en la interacción cara a cara (pero que nosotros extendemos aquí a Facebook) está en relación con la situación interactiva en que surge, provenga de una interacción cara a cara o de una interacción on line. En cualquier caso, la identidad se deposita, despliega y disemina en las propias obras (imágenes, textos) y en el producto de la interacción con los otros.

Sin embargo, nuestro estudio sobre la imagen de perfil de Facebook también nos llevó a considerar nuevos aspectos que no estaban incluidos en la perspectiva goffmaniana; por ejemplo, la perdurabilidad de la imagen de sí, a través del entorno material digital. Mientras en los álbumes de fotos la imagen es mantenida en el tiempo (cumpliendo así un papel "memorioso") y se puede acceder a ella en diferentes momentos y por diferentes personas, en Facebook la audiencia se amplía y deja huellas de su pre y posproducción. No solo es un asunto de "ponerme en escena" o de usar máscaras o gestionar ciertos recursos, en la presentación de sí ante un 
público, pues la socialización y la interacción social en general se complejizan en estas plataformas. Los sujetos deben inventar "cálculos" y tácticas sobre los efectos potenciales de su imagen, actividad que no termina con subir la foto a la página, sino que siempre es susceptible de transformación, actualización y diseminación. Tal asunto se sale del control de los usuarios. También exige acoplarse a las configuraciones técnicas y a la lógica social de la plataforma digital; sin embargo, esto no se produce necesariamente de manera consciente y reflexiva, pues justamente dicha lógica se basa en la idea de la facilidad de uso, de "transparencia", "amigabilidad", "rapidez" y "neutralidad" que favorecen una interacción más "fluida".

En consecuencia, la identidad en estos entornos digitales es una coproducción donde se cruzan las estrategias de la plataforma y las tácticas de los usuarios (Cardon, 2008). De hecho, en nuestro estudio, en relación con los asuntos técnicos, algunas veces vimos restricciones porque incluso en los rasgos de Facebook que parecen insignificantes creemos que influyen en la manera como los sujetos despliegan sus perfiles y las formas de presentación de sí (aunque no los determinan totalmente), y al mismo tiempo vimos potencialidades, como un complemento, porque los usuarios a pesar de esas condiciones encuentran las maneras y los recursos para presentarse (aunque, como también lo señalamos, se acuda a imágenes naturalizadas y estereotipadas de las industrias culturales). El hallazgo sobre la imagen tipo "canon", y de la alta presencia de imágenes bio-gráficas, nos muestra una tendencia a valorar "presentarse al natural" y la emergencia de una práctica social que consiste en estarse "tomando fotos" permanentemente y "narrar la vida cotidiana" (en una oralidad secundaria). Pero al mismo tiempo se destaca que el espacio de imagen de perfil en Facebook tiene una restricción al no ofrecer herramientas de tratamiento visual dentro del entorno. Por lo cual, quienes realizan mayor tratamiento de la imagen deben acudir a otros dispositivos y programas de edición, por fuera de la plataforma Facebook.

Aunque nuestro estudio no se centró especialmente en una población joven, ni es un estudio especializado en temas de juventud, es evidente que el grupo poblacional que con mayor intensidad usan la red social Facebook (y especialmente en términos de producción y creación de contenidos) son las personas más jóvenes. De hecho, esto tiene que ver con la necesidad propia de su edad de explorar su identidad. Una de las principales razones que esta población tiene para pertenecer a la red social Facebook es comunicarse permanentemente con sus pares, con quienes se conforma $y(r e)$ produce una forma de mirar y ser mirado, que como mencionamos antes, en muchos casos está influenciada por el régimen visual que imprimen los medios y las industrias culturales. Pero esta interacción requiere mucha producción y creación (de textos cortos, de imágenes), así como velocidad de respuesta. En particular la 
imagen de sí en Facebook funciona como un símbolo que permite compartir, con las redes de amigos y familiares, un mundo significativo; se ha convertido en una forma "natural" de presentar el yo, donde se comparten pensamientos, sentimientos, valores, gustos, aficiones, sueños, temores. En medio de ello se aprende a interpretar el propio yo y el de otros, y de ese modo consideramos que se están produciendo nuevas formas de subjetividad individual/colectiva.

En Facebook vemos aparecer, al lado de la imagen, formas de reflexividad vinculadas a la escritura hipermedial (Rueda, 2007), en una suerte de oralidad secundaria, en tanto las acciones de la presentación pública se traducen en obras que permanecen (imágenes, textos), y que pueden ser leídas y observadas una y otra vez por otros (una rutina muy común en estas redes sociales es [re]leer, [re]mirar lo que se ha enviado y recibido, así como los comentarios de amistades). Por ello, el proceso de presentación de sí en dicho entorno se hace mucho más complejo y difícil de controlar, pues la integración de las tecnologías digitales a nuestras rutinas diarias es el resultado de una coevolución, un ajuste y una negociación entre unas tradiciones heredadas de la cultura escrita que deviene hipertextual, los regímenes visuales de las industrias de medios y la lógica de mercado y, al mismo tiempo, el deseo de transformación de nuestras sociedades.

Esta nueva reflexividad empieza a ser señalada por varios estudios sobre jóvenes (Cubides, 2010; Gómez, 2012; Rueda y Giraldo, 2014; Gómez et al., 2013; Reguillo, 2012, Miller, 2012). Por una parte, lo que algunos ven como "exacerbación de la exposición del yo", que también lo es (Sibila, 2008), implica asimismo un intercambio intersubjetivo intenso, donde la subjetividad se construye en medio de una multiplicidad de voces y puntos de vista (aunque a veces sea con comentarios del tipo "me gusta" sin más argumentación) en un sistema de escritura hipertextual. Por supuesto, siempre están los riesgos de que con quienes se interactúa tengan también "los mismos punto de vista", prejuicios y estereotipos; al fin y al cabo, son los amigos; pero, en todo caso, están las condiciones dadas (el entramado sociotécnico) para que sean posibles voces múltiples y recíprocas. Esta reflexividad mediada puede incidir en las formas en que la singularidad del yo se transforma en el encuentro con el otro; esto es, donde la identidad en la tensión individualidad/colectividad se intensifica y acelera. ${ }^{15}$

15 Nos queda por discutir las resonancias y diferencias de este planteamiento con la reflexividad estética o expresiva planteada por Lash (200I) en oposición a la cognitiva (propuesta por Giddens y Beck en el famoso texto conjunto Modernización reflexiva), que no es conceptual sino mimética y trae consigo una comprensión de sí, y de prácticas sociales implícitas. Esta reflexividad estética está menos mediada por el sujeto y más motivada por el fenómeno que es representado (la 
No obstante, no podemos olvidar la lógica social que está en la base de estas plataformas digitales, los modos de formalización y automatización de nuestros intercambios sociales, en una suerte de "auto-sociografía" que producimos en dicho ecosistema técnico (Stiegler, 2013), en tanto damos cuenta de manera permanente de nuestros gustos, miedos, sueños, necesidades y las de nuestros amigos, que por medio de la lógica social automatizada de estas plataformas se recopila y distribuye a terceros. Al ponerse en manos del mercado ( $y$ sus reglas de rentabilidad), configura una nueva economía y política. Por ello, conectividad no implica necesariamente colectividad ni trabajo cooperativo, ni subjetividades emancipadas, como afirman algunos optimistas de la cultura digital.

Finalmente, lo paradójico es que la vía que tenemos para resistir a ello también nos la ofrecen las actuales tecnologías digitales. La experiencia de los movimientos sociales y colectivos de activistas, de las comunidades de práctica, de los colaboratorios y de muchos otros experimentos sociales son espacios para compartir formas alternativas de artesanía que desconfían de las soluciones rápidas, de la urgencia de lo "útil y rentable" y confían en una acción creadora y no mecánica, en la riqueza que el cuerpo proporciona (Sennett, 2009), en la capacidad de trabajar colectiva y fraternalmente. Por ello, la vigilancia crítica no está solamente en la academia, sino que está diseminada en las múltiples experiencias que sujetos individuales y colectivos están creando en la nueva infraestructura material. Cada una de estas es siempre una posibilidad de vida, de aprendizaje y de movimiento.

\section{Bibliografía}

Bauman, Zigmund (2007), Tiempos líquidos: vivir en una época de incertidumbre, Tusquets, Barcelona.

Barthes, Roland (1989), La cámara lúcida. Notas sobre la fotografía, Paidós, Barcelona.

capacidad icónica de las llamadas "señales", sobre todo, las producidas por las industrias culturales). Se trata de una reflexividad que hace referencia al uso del cine, la televisión de calidad, la poesía, los viajes y la pintura como medios en la regulación reflexiva de la vida cotidiana. Dicha enumeración nos lleva a afirmar que este tipo de reflexividad posee un rol mayor a la hora de analizar los nuevos procesos de individualización. De esta manera los modelos de subjetividad a los que conduce este tipo de reflexividad están basados en el cultivo del deseo, la imaginación creadora, lo afectivo y lo placentero. 
Benjamin, Walter (1973), La obra de arte en la época de su reproductibilidad técnica, Taurus, Madrid.

Berry, David (201I), The Philosophy of Software: Code and Mediation in the Digital Age, Palgrave, Londres

Bringué, Xavier y Maria Rosario Sádaba Ch. (coords.) (2008), La generación interactiva en Iberoamérica: Niños y adolescentes ante las pantallas, Fundación Telefónica/Ariel, Barcelona.

Cubides, Humberto (2010),"Trazos e itinerarios de diálogos sobre política con jóvenes contemporáneos de Bogotá", Nómadas, 32, pp.59-80.

Dussel, Inés (20I0), "Aportes de la imagen en la formación docente. Abordajes conceptuales y pedagógicos", tomado de: <http://repositorio. educacion.gov.ar/dspace/bitstream/handle/123456789/89762/Pedagog $\% \mathrm{C}_{3} \% \mathrm{ADas} \% 20 \mathrm{de} \% 20$ la $\% 20$ imagen..pdf? sequence $=$ I $>$ [ I2 de abril de 2013].

Cardon, Dominique (2008), "Le design de la visibilité : Un essai de cartographie du web 2.0", Réseaux, 6(152), pp. 93-137

Dijck, José van (2008),"Digital photography: communication, identity, memory", Visual Communication, 7(I), pp. 57-76.

(2013), "You have one identity: performing the self on Facebook and LinkedIn", en Media, culture E society, 2(35), pp. 199-215.

Dijck, José van y Thomas Poell (2013),"Underestanding social media logic”, Media and Communication, vol I, pp. 2-I4. DOI: I0.12924/mac2013.0I.010002.

Fontcuberta, Joan (2010), La cámara de Pandora.La fotografi@ después de la fotografía, Gustavo Gilli, Barcelona.

Goffman, Erving (1959), Presentation of Self in Everyday Life, Doubleday Anchor, Nueva York.

(1979), Gender Advertisements, Harper and Row, Nueva York.

Giddens, Anthony (1991), The Consequences of Modernity, Polity Press, Cambridge.

Gómez Zúñiga, Rocío y Julián González Mina (2009),"Formas de presentación pública de la persona en Facebook", Nexus, 5, pp. 54-65

(20I2), "Rutas y configuraciones de la imagen de perfil en Facebook", Documento interno de trabajo, Universidad del Valle, Cali.

Gómez Zúñiga, Rocío et al. (2013), "Formas de presentación de la persona en Facebook", Informe final de investigación, Universidad del Valle, Cali. 
Herrera, Martha Cecilia et al. (2005), La construcción de la cultura politica en Colombia. Proyectos hegemónicos y resistencias culturales, Universidad Pedagógica Nacional, Bogotá.

Miller, Daniel (2012), Das wilde Netzwerk. Ein ethnologischer Blick auf Facebook, Suhrkamp, Berlín.

Ministerio de Tecnologías de la Información y las Comunicaciones, MINTIC (2014), Estudio de cultura digital en Colombia, <http://www.mintic.gov. $\mathrm{co} /$ portal/604/w3-article-6096.html $>$ [30 de mayo de 2014].

Muñoz, Germán (2006), La comunicación en los mundos de vida juveniles: Hacia una ciudadanía comunicativa, tesis de doctorado inédita, Universidad de Manizales.

Quintana, Antonio (2010), "De la cultura juvenil a la cibercultura juvenil: más allá del prefijo del ciber”, Educación y ciudad, I8, pp 77-92

Reguillo, Rossana (2012), "Navegaciones errantes. De músicas, jóvenes y redes: de Facebook a youtube y viceversa", en Comunicación y sociedad, I8, julio-diciembre, pp. 135-I7I

Rueda Ortiz, Rocío (2012a),"Formas de presentación de sí en Facebook: Esbozos de una poética y estética dialógica”, Nexus, I2, pp. 202-215 (20I2b), "Educación y cibercultura en clave subjetiva: retos para (re) pensar la escuela hoy”, Educación y Pedagogía, 24(62), pp. 157-172 (20I2c), "Sociedades de la información y el conocimiento: Tecnicidad, Pharmakon e invención social”, Nómadas, 36, pp. 43-55.

(2007),"Para una pedagogía del hipertexto: una teoría entre la deconstrucción y la complejidad”, Anthropos, Barcelona.

Rueda Ortiz, Rocío, David Fonseca y Lina Ramírez (eds.) (2013), Ciberciudadanias, cultura politica y creatividad social, tesis de doctorado inédita, Universidad Pedagógica Nacional, Bogotá.

Rueda Ortiz, Rocío y Diana Giraldo (en prensa),"Profile image: ways of self(re) presentation on the Facebook social network", en B. Saegret (ed), Youth 2.0: Connecting, Sharing and Empowering. University of Antwerpen \& Springer, Bélgica.

Schraube, Ernst (1998), Auf den Spuren der Dinge. Psychologie in einer Welt der Technik, Argument-Verlag, Hamburgo.

Sennett, Richard (2009), El artesano, Anagrama, Barcelona.

Serrano-Puche, Javier (2013),"Vidas conectadas: tecnologías digital, interacción social e identidad”, en Historia y Comunicación Social, I8, pp. 353-364

Sibilia, Paula (2008), La intimidad como espectáculo, FCE, Buenos Aires. 
Stiegler, Bernard (2013),"The most precious good in the era of social technologies", en G. Lovink y M. Rasch (eds.), Unlike Us Reader. Social Media Monopolies and their Alternatives, Institute of Network Cultures, Ámsterdam, pp. 16-30

Hollenstein, Tom (2007), "State space grids: Analyzing dynamics across development", International Journal of Behavioral Development, 4(3i), pp. 384-396.

Winocur, Rosalía (2012), "La intimidad de los jóvenes en las redes sociales. Transformaciones en el espacio público y privado", Telos: cuadernos de comunicación e innovación, 91, pp. 79-88 